\title{
Review on the petroleum market in China: history, challenges and prospects
}

\author{
Si-Yuan Chen ${ }^{1,2} \cdot$ Qi Zhang $^{1,2} \cdot$ Benjamin Mclellan ${ }^{3} \cdot$ Tian-Tian Zhang ${ }^{1,2}$
}

Received: 5 February 2020 / Published online: 30 August 2020

(c) The Author(s) 2020

\begin{abstract}
The petroleum industry plays an essential role in driving China's economic development. In the past few decades, several reforms in the petroleum industry have been implemented; however, there are still some issues that have not been resolved. Moreover, with the new-normal economy, the transition to green energy and international trade disputes, the petroleum market is also facing emerging challenges. Therefore, the purpose of the present study is to review the historical development of China's petroleum market, identify the current challenges and propose corresponding countermeasures for future prospects. As a conclusion, five main challenges are highlighted totally, namely lack of marketization, excess oil refining capacity, high external dependency, environment pollution and unstable international trading relationship. To address these challenges, it is encouraged to deepen petroleum market reform, accelerate the elimination of inefficient refining capacity, diversify oil supply sources, as well as improve domestic petroleum enterprises' ability to resist price risks.
\end{abstract}

Keywords China's petroleum market $\cdot$ Petroleum products $\cdot$ Market reform

\section{Introduction}

Since the 1990s, the growth of Chinese oil consumption has accelerated dramatically due to the rapid growth of the domestic economy (Leung 2010). A stable supply of petroleum resources is currently essential to improve China's socio-economic development, as petroleum products are almost used in every sector (Tang et al. 2011). By the end of 2018, China's oil consumption was up to 877.0 million tonnes of standard coal and growing at a rate of $4.0 \%$ p.a., accounting for $18.9 \%$ of total primary energy consumption, second only to coal, as shown in Fig. 1. Moreover, petroleum products consumption reached 356.9 million tonnes in 2017, as shown in Fig. 2. The Chinese petroleum industry is

Edited by Xiu-Qiu Peng

Qi Zhang

zhangqi56@tsinghua.org.cn

1 School of Economics and Management, China University of Petroleum-Beijing, Beijing 102249, China

2 Academy of Chinese Energy Strategy, China University of Petroleum-Beijing, Beijing 102249, China

3 Graduate School of Energy Science, Kyoto University, Kyoto, Japan predicted to grow steadily in the coming decades, continuing to account for a stable share of around $20 \%$ of the total primary energy mix (Yang et al. 2016).

However, a number of factors are impeding the further development of China's petroleum industry. For example, most of the petroleum market is controlled by the three major state-owned oil companies, resulting in a lack of competitiveness and flexibility in the market. Moreover, regulated prices of petroleum products cannot accurately reflect their intrinsic value, causing an imbalance between oil supply and demand. In order to further release the domestic petroleum market, the Chinese government has introduced a series of policies, including the Regulatory Approach on Oil and Gas Pipeline Facilities Fair and Open issued by China's National Energy Administration (NEA) in 2019 (NEA 2019). This provision allows third-party market entities to use pipe network facilities, which is crucial for breaking the natural monopoly in the midstream of the petroleum industry. In terms of the pricing mechanism, the State Council promulgated Opinions on Promoting the Reform of the Price Mechanism in 2015 to deregulate the prices of petroleum products (the State Council 2015). Despite the introduction of these policies and regulations, some critical issues remain unsolved, such as low marketization level and high external dependency. Furthermore, with China's economy 


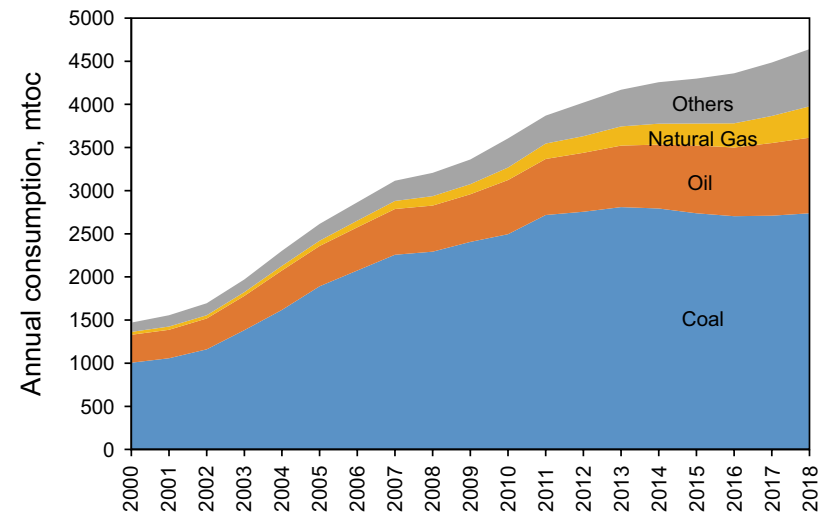

Fig. 1 China's primary energy consumption structure. Source: China statistical yearbook, National Bureau of Statistics of China

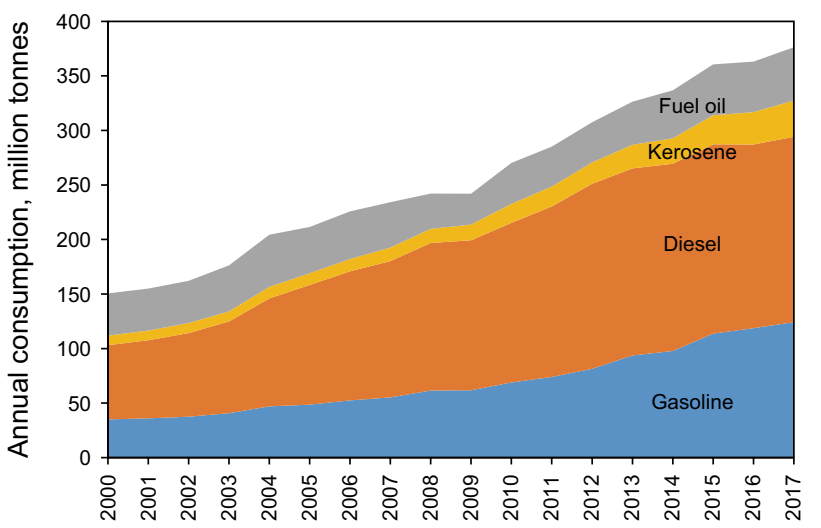

Fig. 2 China's petroleum products consumption structure. Source: China statistical yearbook, National Bureau of Statistics of China

moving into the "new normal" phase, the promotion of green energy transition strategy and the outbreak of world trade disputes, the petroleum industry is facing new problems and challenges.

Several existing studies have analyzed the impacts and challenges of China's petroleum market reform through quantitative or qualitative methods. For example, the effects of petroleum products pricing reform on the Chinese stock market were examined (Bouri et al. 2017; Wen et al. 2018), along with its influences on the passenger transportation (Lin and Liu 2013). Similarly, the impacts of upstream market reform on pipeline deployment were also explored ( $\mathrm{Li}$ et al. 2018). With the release of crude oil imports, a dynamic game-theoretic model was established to seek the optimal oil import/export quotas for non-state-owned refineries (Chen et al. 2017). Moreover, the potential for energy saving of China's petroleum industry has been estimated from a technical perspective (Liu et al. 2013), while the risks of China's oil security and corresponding mitigation measures have been analyzed from the perspective of the supply chain
(Zhao and Chen 2014; Sun et al. 2017a, b; Xie et al. 2017). However, few studies have comprehensively summarized the emerging challenges and prospects faced by China's petroleum market.

In order to fill the gap in the previous literature, the present study provides an overview of the historical development and challenges facing China's petroleum industry, followed by the proposal of corresponding countermeasures and prospects. The structure of the remainder of this paper is as follows: Sect. 2 summarizes the historical development of China's oil markets from four aspects of its administration, industrial and market structures, oil imports and pricing mechanism; Sect. 3 discusses the main challenges faced by China's petroleum industry; corresponding countermeasures are then given in Sect. 4, followed by the conclusions in Sect. 5 .

\section{Historical development of China's petroleum market}

The historical development of China's petroleum market is examined from the following four perspectives: (i) administration; (ii) industrial and market structures; (iii) oil imports; and (iv) pricing mechanism. This section describes the evolution of the petroleum market by reviewing relevant policies.

\subsection{Administration}

The administration of the petroleum industry has undergone several changes since China's reform and opening up. As shown in Fig. 3, the National Energy Commission was established in 1980 to exercise comprehensive management over the petroleum, coal and power industries. Two years later, such integration was abolished, and the Ministry of Petroleum Industry was established. In 1988, the State Council carried out an institutional restructure and established the Ministry of Energy as the competent authority for the petroleum industry. In 1998, the Bureau of Petroleum and Chemical Industry was formed under the State Economic and Trade Commission to replace the Ministry of Energy, while the Bureau was removed in 2001. In 2003, the Energy Bureau was founded, the predecessor of the NEA. In 2008, the National Development and Reform Commission (NDRC) set up the NEA. In 2010, the State Council established the National Energy Commission in charge of strategic decisions and the overall coordination of the energy sector (Sheng and Qian 2015).

The changes in the administration of the petroleum industry show an alternation of stand-along and integrated management over the petroleum industry. The administration of Chinese petroleum enterprises has also experienced big 


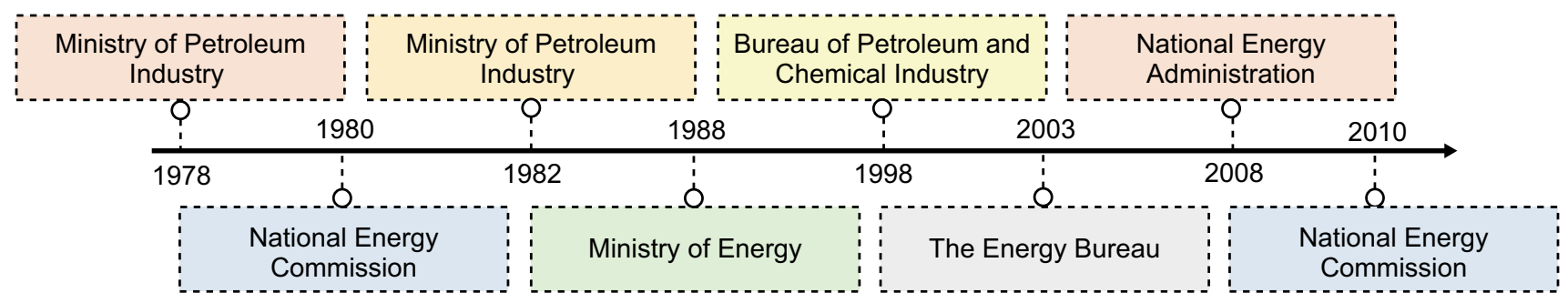

Fig. 3 Changes in administration of the petroleum industry

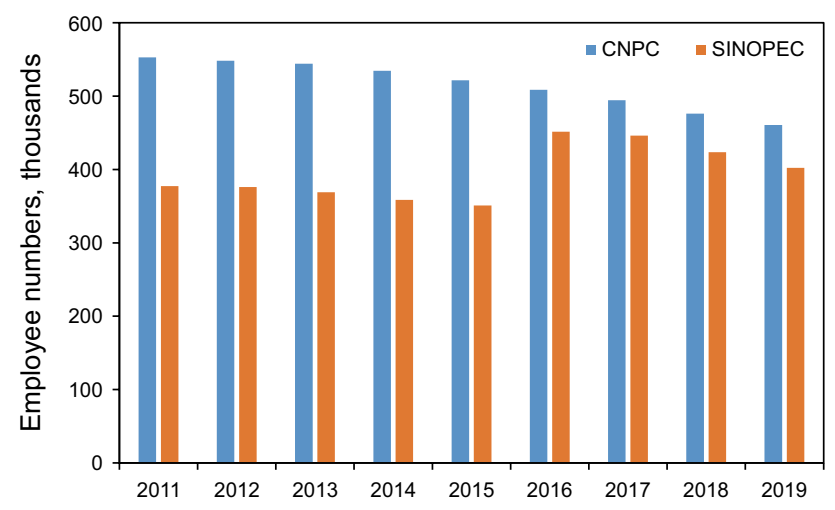

Fig. 4 Employee numbers in CNPC and SINOPEC. Sources: Annual reports of CNPC and SINOPEC

changes in the past decade. As shown in Fig. 4, employee numbers of CNPC have decreased to 460.7 thousand by 2019 , with an annual average rate of $-2.1 \%$. Different from CNPC, SINOPEC had a turning point in 2016, with a significant increase of 100.6 thousand in employee numbers. Note that $97 \%$ of new employees were engaged in marketing and distribution, as a result of SINOPEC's market expansion in the downstream.

\subsection{Industrial and market structures}

China's economic system was a thoroughly planned economy before 1978. Under this system, China's petroleum market was characterized by low efficiency, leading to a decline in oil production and heavy losses suffered by petroleum enterprises (Sheng and Qian 2015). To improve this situation, the government has implemented several reforms since 1978, eventually creating the current industrial pattern mainly comprised of three state-owned enterprises.

As shown in Fig. 5, the Chinese government has issued a series of policies to reform the organization and structure of the petroleum industry and markets since 1978. As a result, China's petroleum industry structure went through several changes, as shown in Fig. 6. From 1982 to 1998, the state successively established China National Offshore Oil Corporation (CNOOC), China Petrochemical Corporation
(SINOPEC), and China Petroleum and Gas Corporation (CNPC). These three enterprises were responsible for different businesses: CNPC was in charge of the exploration of onshore oil; SINOPEC was accountable for oil refining and pipeline construction, while CNOOC was engaged in the exploitation of offshore oil. In 1998, China's petroleum industry was restructured, and these three petroleum enterprises were all changed to vertically integrated companies. What remains constant is that CNOOC is still mainly engaged in offshore oil production and investment, while CNPC and SINOPEC are onshore oil production companies (Zhang 2004). Moreover, in order to raise funds from overseas capital markets, the listed entities of PetroChina Ltd, Sinopec Ltd and CNOOC Ltd were created, which are majority-owned by the wholly state-owned enterprises CNPC, SINOPEC and CNOOC, respectively (AndrewsSpeed and Cao 2005; Kong 2010).

To enhance the administrative monopoly status of CNPC and SINOPEC, supportive policies were introduced. In 1999, the State Council enacted the Suggestions on Clearing and Rectifying Small Refinery Plants and Regulating the Circulation Order of Crude Oil and Petroleum Products, which required CNPC and SINOPEC to purchase non-stateowned refineries with the annual capacity of more than 1 million tonnes. Two years later, the State Council approved CNPC and SINOPEC had the exclusive right to sell petroleum products. In 2003, the Ministry of Railways issued the Notice on Strengthening the Management of Oil transportation (Tie Yun Hao No. 150 Decree), clearly stipulating that the railway can only transport petroleum products of CNPC and SINOPEC. Subsequently, NDRC ruled that only CNPC and SINOPEC had the right to supply ethanol gasoline for vehicles.

With the deepening of market-oriented reform of China's petroleum industry, the competition in the downstream is becoming increasingly fierce. In 2006, the Ministry of Commerce promulgated the Measures for Management of Petroleum Products Market to open the wholesale and retail rights of petroleum products to foreign enterprises, which came into effect from January 1, 2007. Since then, the market share of foreign enterprises has been increasing. However, such an increase has not broken the dominance of those three 


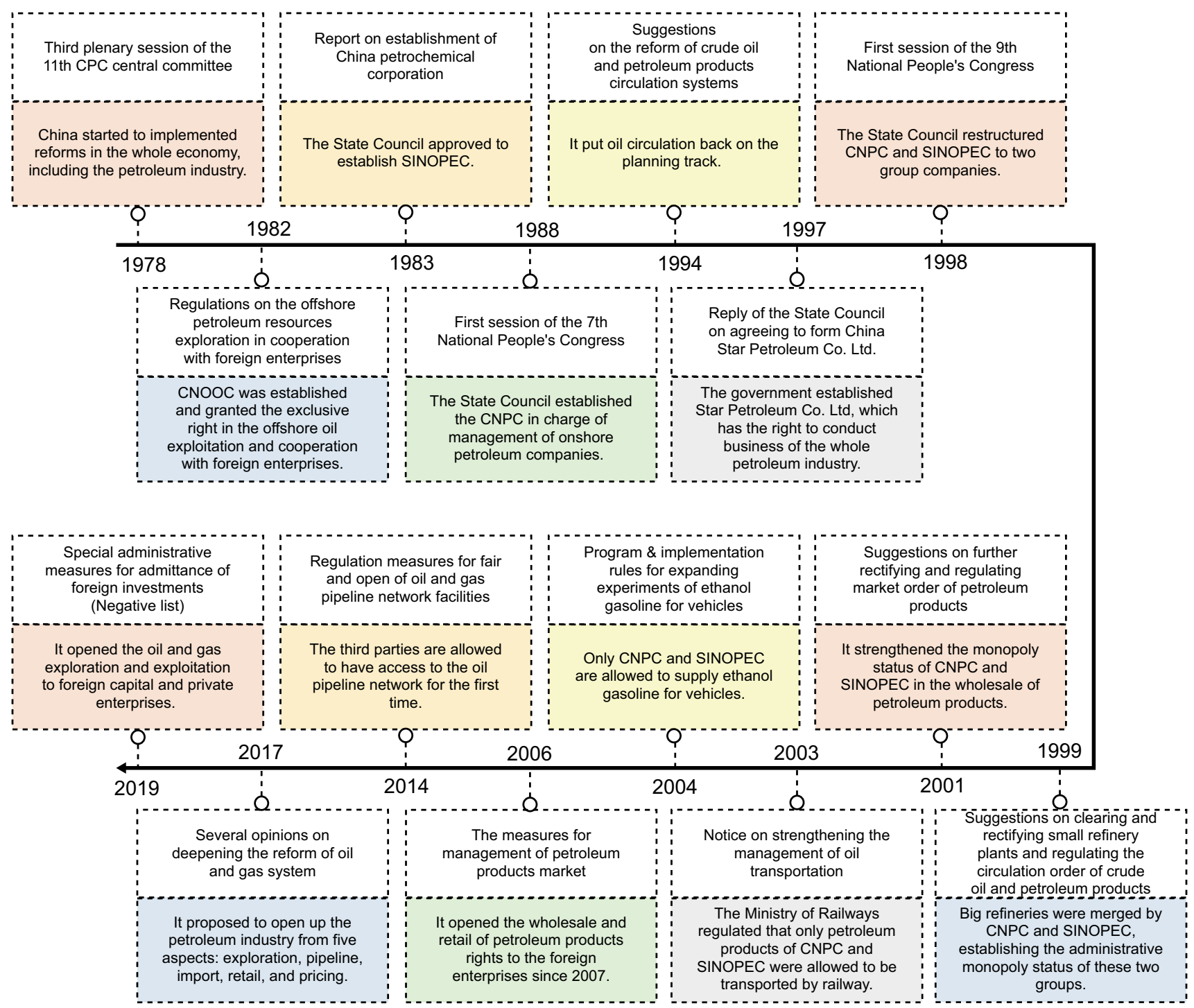

Fig. 5 The history of the petroleum industrial and market reforms

state-owned enterprises. To further promote the marketization of the petroleum industry, the State Council published Several Opinions on Deepening the Reform of the Oil and Gas System in May 2017, which declared the intention to fully open up the petroleum industry. As shown in Fig. 7, non-state-owned gasoline stations accounted for $45.4 \%$ by the end of 2018, and foreign enterprise will play a greater role in the retail market of petroleum products.

\subsection{Oil imports}

China imposed strict controls on oil imports to help maintain order in the domestic market. Under the system, China National Chemical Import and Export Corporation was the only company that had the exclusive right to import and allocate crude oil. As shown in Fig. 8, with the increase in imported oil, the Chinese government released administrative policies to decentralize the import rights. In 1994, the State Council and the Ministry of Foreign Trade and Economic Cooperation (MOFTEC) carried out an approved operation administration of crude oil and petroleum products imports. In 1999, MOFTEC issued the Circular on Issuing the Measures for Organizing the Implementation of the Import of Crude Oil and Finished Oil. In this regulation, four import agent enterprises engaged in the general trade of crude oil and petroleum products were proposed, namely China Chemicals Import and Export Corporation, China International Petroleum Chemicals Allied Corporation, China Petroleum Allied Corporation and Zhuhai Zhen Rong Company (MOFTEC 1999).

China has accelerated its reform of oil imports after it entered the World Trade Organization (WTO) in 2001. 


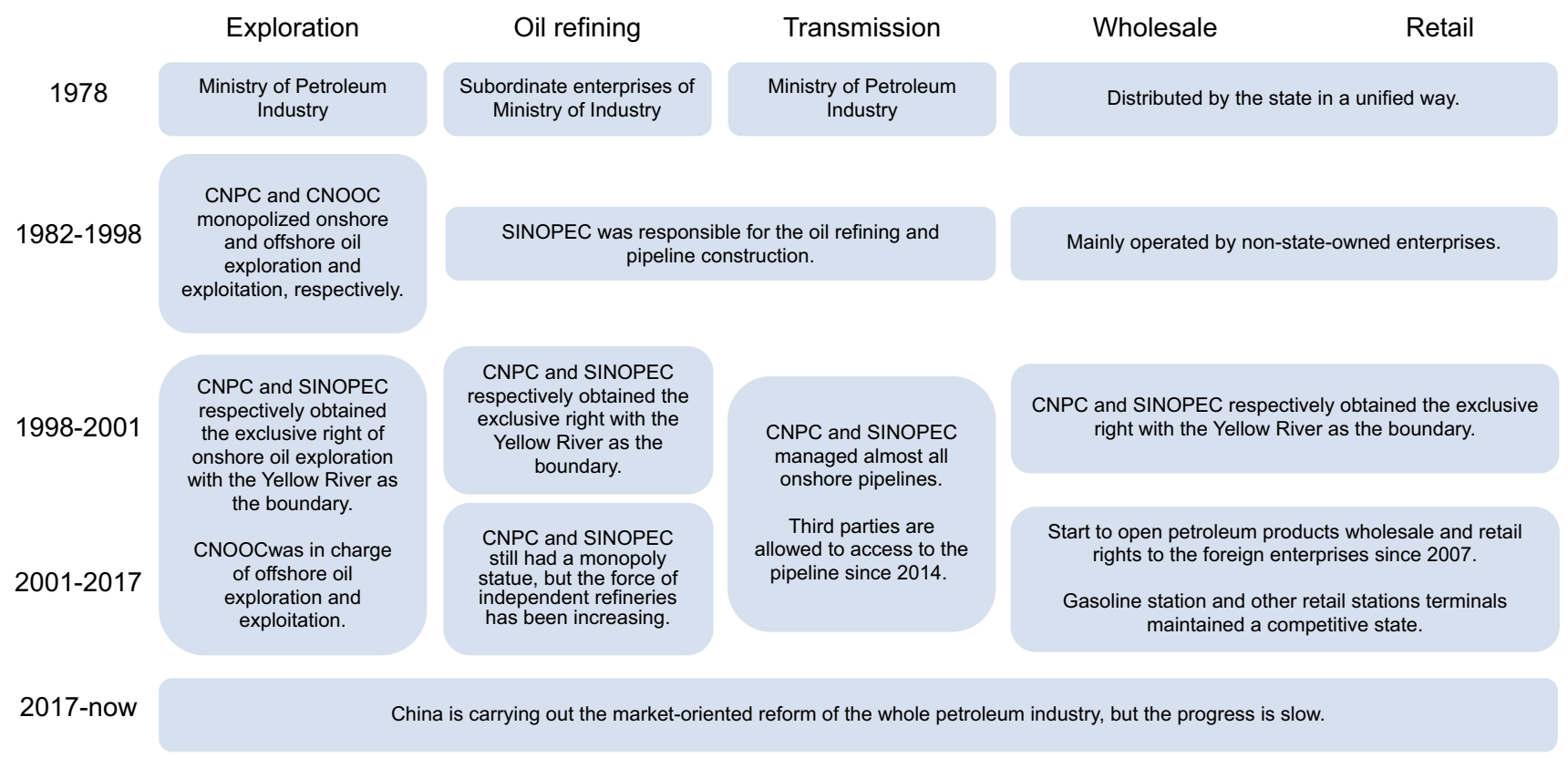

Fig. 6 Historical development of China’s petroleum industry structure (Since 1978). Source: Adapted from Sheng and Qian (2015)

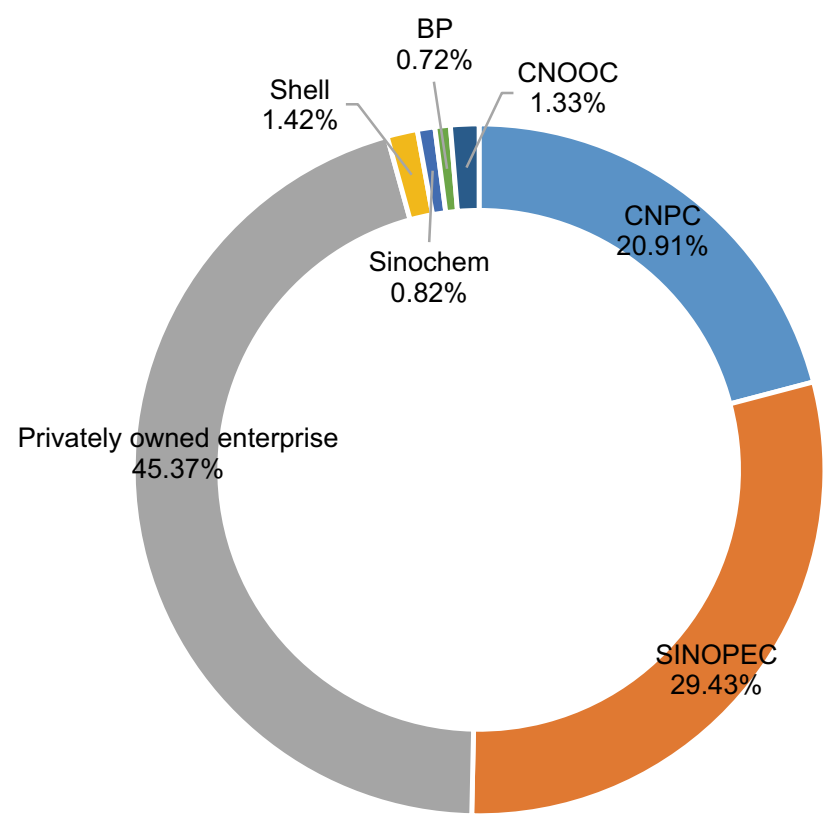

Fig. 7 Market structure of China's gasoline stations in 2018. Source: Annual report 2018 of CNPC and SINOPEC; Qianzhan Industry Research Institute

One of the significant changes was to divide crude oil import into state and non-state trades. The state-run trade carries out an automatic import license administration, without quantitative limits. State-owned entities with import rights include Sinochem Group, China National United Oil Corporation (subordinate to CNPC), China
International United Petroleum \& Chemicals Co., Ltd. (subordinate to SINOPEC), CNOOC and Zhuhai Zhen Rong Company. The imports of these five enterprises hold about $90 \%$ of total domestic imported crude oil (Wang et al. 2016b). As for the non-state trade, quota management was implemented. According to the pledge of the Chinese government to the WTO, the non-state import quotas of crude oil would increase by $15 \%$ annually from 2001. Figure 9 presents the actual import quotas of crude oil for non-state trade along with total crude oil imports. It demonstrates a significant increase in import quotas after 2014 and is estimated to increase to approximately half of the total crude oil imports by 2019 .

In 2013, the State Council promulgated Several Opinions on Promoting the Growth Stabilization and Structural Adjustment of Imports and Exports to allow oil refineries that meet the standards to import and use crude oil (the State Council 2013). One year later, the State Council issued Several Opinions on Supporting the Steady Growth of Foreign Trade, re-emphasizing a strong need to open the right to import crude oil for independent refineries (the State Council 2014). In 2016, the Ministry of Commerce increased the non-state trading import quotas to 87.6 million tons, rising by $133 \%$ from 2015. In that July, Dongming Petrochemical Company became the first independent refinery to obtain the right to use and import crude oil. By April 2017, there were 23 independent refineries with imported crude oil use rights and import qualifications (Wang and She 2017). In 2018, the Ministry of Commerce announced the import quotas of nonstate trade in 2019 would be 202 million tonnes, increasing 


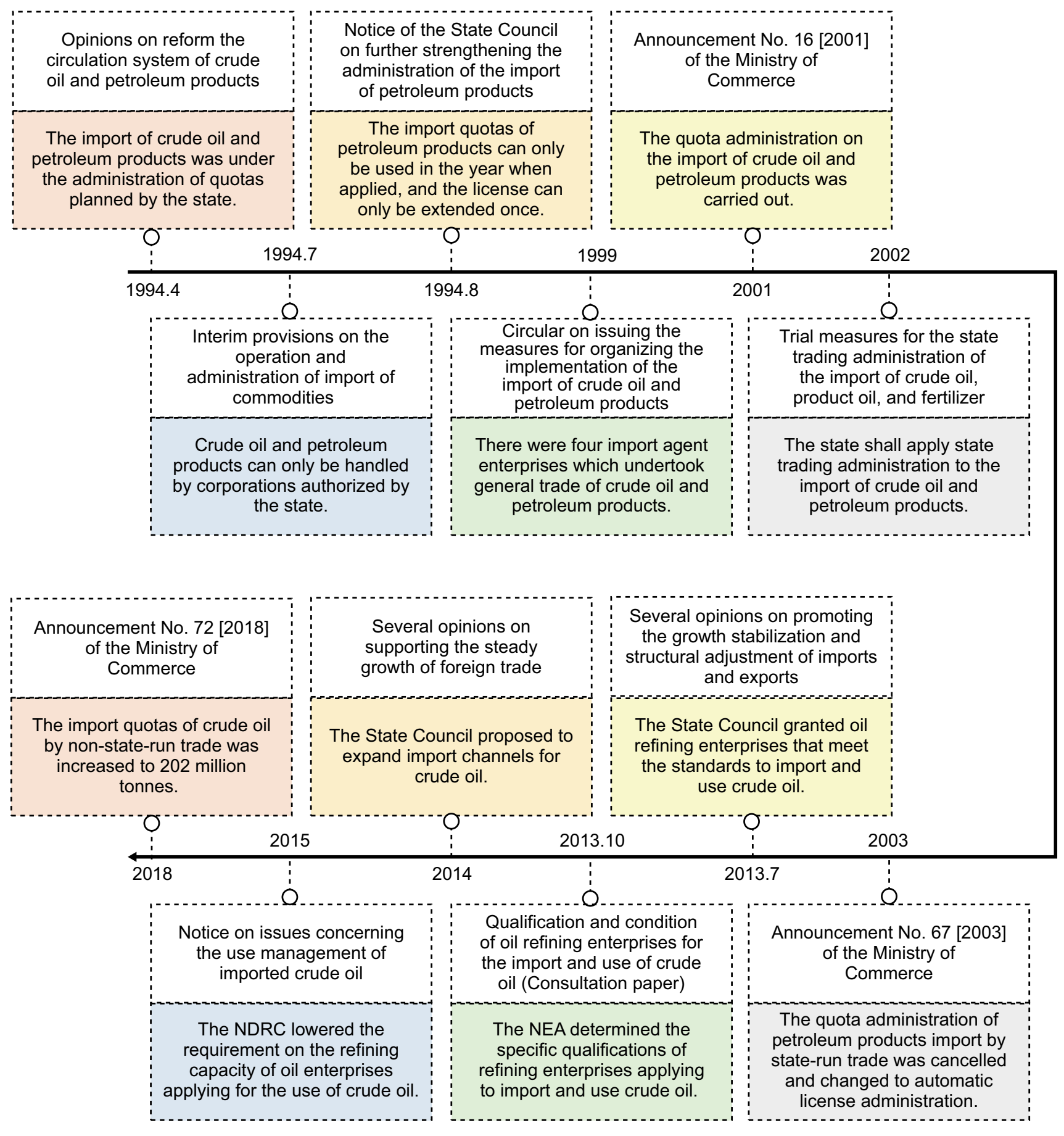

Fig. 8 The history of the oil import reform

by $41.8 \%$ of 2018 , which indicates the further release of oil import rights (Ministry of Commerce 2018).

\subsection{Pricing mechanism}

China's petroleum products pricing mechanism has experienced a long path of reform, which developed from a single price to the price being determined according to the international oil price (Zhang and Xie 2016). As a strategic resource, crude oil and petroleum products were uniformly allocated by the state at the start, with the prices formulated and controlled by the government. However, there exist drawbacks to this kind of planned system. Firstly, the government cannot accurately predict consumers' preference, surpluses and shortages, so that they could not efficiently allocate oil resources. Secondly, petroleum enterprises have 


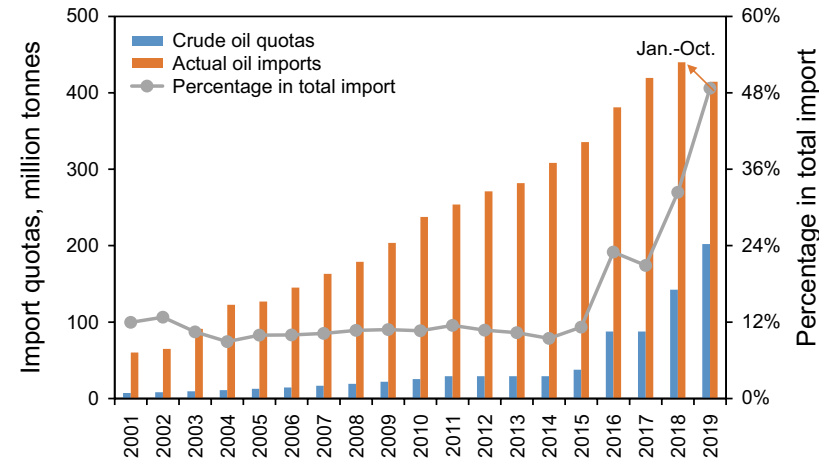

Fig. 9 Import quotas of crude oil for non-state trades

no incentive to innovate or take entrepreneurial risks, as the price is controlled by administrative regulation. Consequently, a pricing reform of the petroleum market was launched in 1998. Under this reform, Chinese crude oil can be classified as four types: Light, Medium I, Medium II and Heavy, and different types of crude oil have different pricing benchmarks. In detail, the price of Light crude oil is associated with that of a Malaysian crude oil, which is used as a pricing benchmark in Singapore and Australia. The price of Medium I and Medium II is linked to that of Minas and Cinta, respectively. Meanwhile, the price of Heavy referred to that of Duri (Li and Leung 2011). Government guide-price for petroleum products remained unchanged if the international oil price fluctuates within the range of 5\%-8\%. Other changes in the pricing mechanism for crude oil and petroleum products are also summarized as shown in Table 1.

\section{Challenges for China's petroleum market}

\subsection{Lack of marketization}

\subsubsection{Domination of state-owned enterprises}

Three state-owned enterprises play a dominant role in China's petroleum industry (Lee 2009; Walls 2010). CNPC had a domestic crude oil production of 100.1 million tonnes in 2019 , accounting for $52.4 \%$ of total crude oil output. The company processed 166.2 million tonnes of crude oil and produced petroleum products of 117.8 million tonnes (CNPC 2020). SINOPEC produced 35.1 million tonnes of crude oil within the territory of China in 2019, refined 248.2 million tonnes of crude and yielded petroleum products of 160.0 million tonnes (SINOPEC 2020). CNOOC's crude oil production was 36.3 million tonnes, with overseas oil production of 18.4 million tonnes (CNOOC 2020). Moreover, the total number of gasoline stations of CNPC and
SINOPEC reached 52,500 in 2018, with a market share of nearly 50\% (Deloitte 2019).

An administrative monopoly in the petroleum industry was proved to bring about huge social welfare losses. The welfare losses consist of three parts: (i) net welfare loss; (ii) net welfare loss from cost increase caused by monopoly; (iii) welfare transfer and loss caused by sellers'/buyers' monopoly price (Sheng et al. 2015; Sheng and Qian 2015). According to data from 2001 to 2011, annual welfare losses caused by an administrative monopoly in the petroleum industry were estimated to be RMB 3.477 trillion, and the welfare losses kept increasing with an increment of RMB 600 billion to RMB 700 billion annually (Sheng and Qian 2015).

Under the current system, the management efficiency of China's listed petroleum enterprises is much lower than that of overseas petroleum enterprises, which is to some extent caused by the lack of internal competition. This also results in lower per capita benefits. As shown in Table 2, according to annual reports of PetroChina and BP, the operating income of PetroChina was 2516.8 billion RMB and it had approximately 460,700 employees in 2019 , while the operating income of BP was 1809.3 billion RMB and it had approximately 70,100 employees. The value created by an individual employee of PetroChina is only $21.2 \%$ of BP. On the other hand, employee costs of PetroChina are higher and the difference between PetroChina and BP is rising year by year. As shown in Fig. 10, employee costs of PetroChina were more than twice that of BP in 2019 and showed a higher proportion of the total operating cost. That is, taking $\mathrm{BP}$ as a benchmark, PetroChina has redundant employees and higher employee costs.

\subsubsection{Inflexible pricing mechanism}

While undergoing several reforms in the last 2 decades, China's oil pricing mechanism still has its problems. Under the current pricing mechanism, the adjustments of domestic petroleum prices were limited, and the adjustment interval is 10 working days. As shown in Table 3, the local gasoline price increased by $8.3 \%$ in 2019 , while the diesel price raised by $9.5 \%$. However, such adjustments cannot flexibly reflect real supply-demand relationships. Instead, this mechanism creates opportunities for speculators and undermines the regular market order. Furthermore, it was found that domestic petroleum products prices lagged behind the international oil price based on the Autoregressive Distributed Lag model (Zhang and Xie 2016).

To protect consumers, the Chinese government uses a range of policies to keep domestic petroleum products prices stable, including setting price ceilings and float ranges, requiring oil companies to bear some or all subsidy costs, imposing export restrictions and lower tax rate (Kojima 2013). Reversely, developed countries levy higher taxes, 


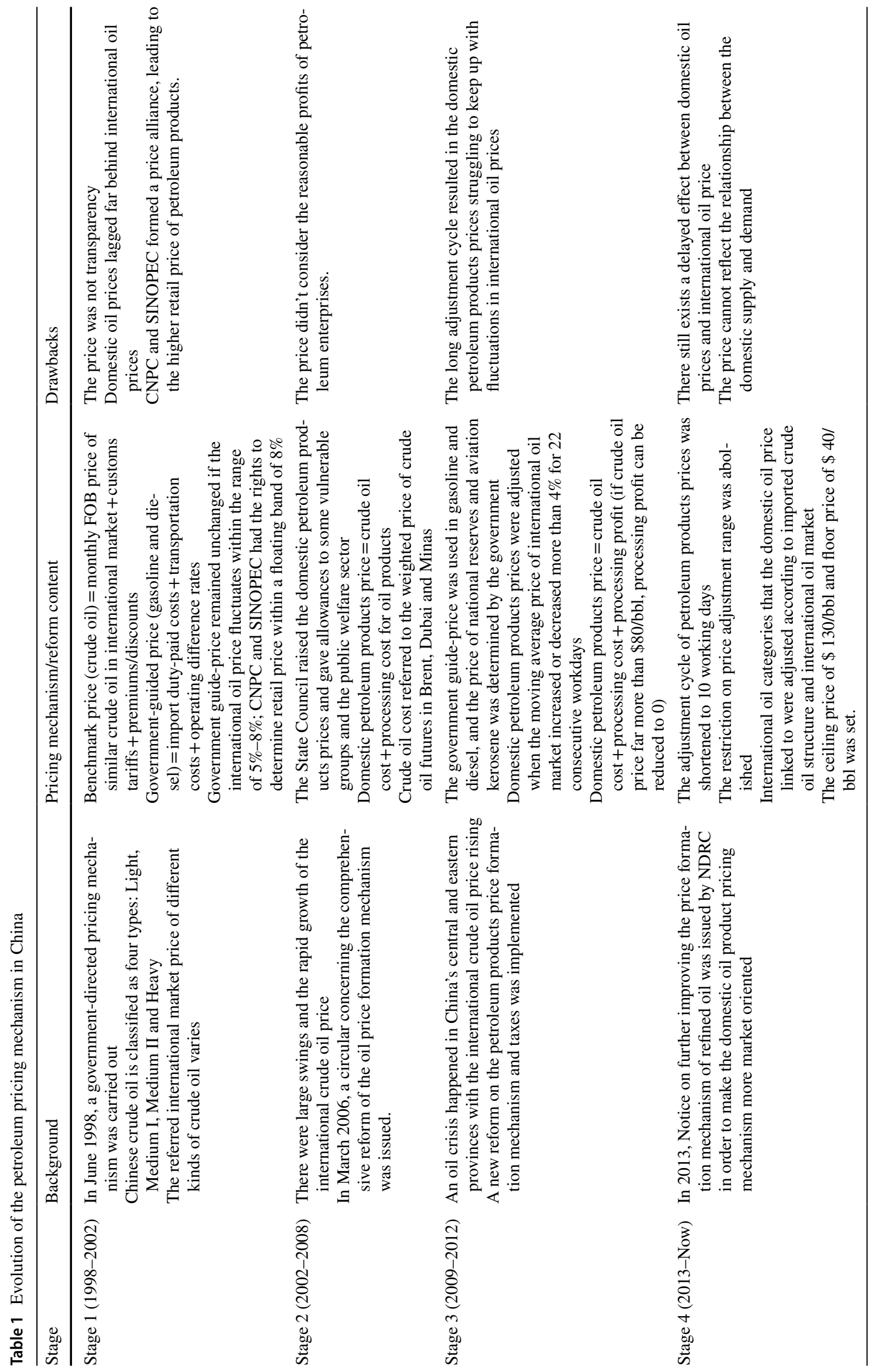


Table 2 Comparison between employee numbers and operating income of PetroChina and BP. Sources: Annual report of PetroChina and BP

\begin{tabular}{|c|c|c|c|c|c|c|}
\hline & \multicolumn{3}{|l|}{ PetroChina } & \multicolumn{3}{|l|}{$\mathrm{BP}$} \\
\hline & $\begin{array}{l}\text { Employee numbers }{ }^{\mathrm{a}} \\
\text { (thousands) }\end{array}$ & $\begin{array}{l}\text { Operating Income } \\
\text { (million RMB) }\end{array}$ & $\begin{array}{l}\text { Ratio (thousand } \\
\text { RMB/employee) }\end{array}$ & $\begin{array}{l}\text { Employee numbers } \\
\text { (thousands) }\end{array}$ & $\begin{array}{l}\text { Operating Income } \mathrm{e}^{\mathrm{b}} \\
\text { (million RMB) }\end{array}$ & $\begin{array}{l}\text { Ratio (thousand } \\
\text { RMB/employee) }\end{array}$ \\
\hline 2011 & 552.8 & $2,003,843$ & 3624.83 & 84.1 & $2,423,039$ & $28,811.40$ \\
\hline 2012 & 548.4 & $2,195,296$ & 4003.42 & 86.4 & $2,423,374$ & $28,048.31$ \\
\hline 2013 & 544.1 & $2,258,124$ & 4150.33 & 83.9 & $2,445,114$ & $29,143.20$ \\
\hline 2014 & 534.7 & $2,282,962$ & 4270.00 & 64.8 & $2,280,222$ & $35,188.61$ \\
\hline 2015 & 521.6 & $1,725,428$ & 3308.17 & 59.4 & $1,437,482$ & $24,200.04$ \\
\hline 2016 & 508.8 & $1,616,903$ & 3178.14 & 74.5 & $1,180,251$ & $15,842.29$ \\
\hline 2017 & 494.3 & $2,015,890$ & 4078.30 & 74.0 & $1,549,143$ & $20,934.37$ \\
\hline 2018 & 476.2 & $2,353,588$ & 4942.20 & 73.0 & $1,926,730$ & $26,393.56$ \\
\hline 2019 & 460.7 & $2,516,810$ & 5462.73 & 70.1 & $1,809,330$ & $25,810.70$ \\
\hline
\end{tabular}

${ }^{a}$ Exclude temporary and retired workers

${ }^{\mathrm{b}}$ Exchange at an average rate of 6.4991 RMB/USD from 2011 to 2019

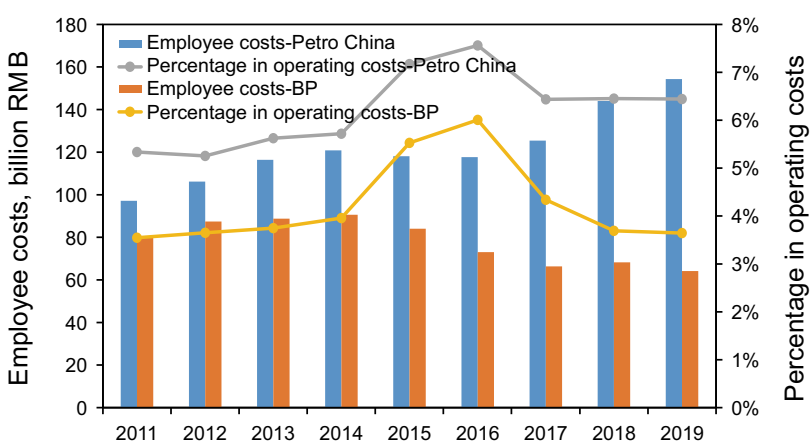

Fig. 10 The comparison of employee costs between PetroChina and BP. Sources: Annual report of PetroChina and BP

such as $64 \%$ on gasoline and $50 \%$ on diesel in Belgium (Yang et al. 2009). As a result, China's petroleum products prices are lower than in most developed countries. As shown in Fig. 11, domestic gasoline and diesel prices are \$12.34/ barrel and $\$ 16.96 /$ barrel lower than the world average. In the future, there is a high probability that petroleum products prices will increase with the opening of the oil market, which may affect the national average price index and increase China's financial burden (Tang et al. 2011).

\subsubsection{Immature Petro-finance market}

The formal launch of the Shanghai International Energy Exchange (INE) in March 2018 indicated that China's Petro-finance market has entered a new phase. The introduction of Yuan-led crude oil futures has not only enhanced the ability of Chinese petroleum companies to control price risks but also made a significant contribution to the internationalization of RMB (Ji and Zhang 2019). However, there are still deficiencies in the current
Table 3 Changes of petroleum products prices in China's market in 2019

\begin{tabular}{|c|c|c|c|c|}
\hline \multirow[t]{2}{*}{ Date } & \multicolumn{2}{|l|}{ Gasoline } & \multicolumn{2}{|l|}{ Diesel } \\
\hline & RMB/tonnes & Change (\%) & RMB/tonnes & Change (\%) \\
\hline 2019/12/31 & 7955 & 3.0 & 6960 & 3.4 \\
\hline 2019/12/17 & 7720 & 0.0 & 6730 & 0.0 \\
\hline $2019 / 12 / 3$ & 7720 & 0.9 & 6730 & 1.0 \\
\hline 2019/11/19 & 7650 & 0.9 & 6665 & 1.0 \\
\hline $2019 / 11 / 5$ & 7580 & 1.4 & 6600 & 1.6 \\
\hline 2019/10/22 & 7475 & -2.0 & 6495 & -2.2 \\
\hline 2019/9/19 & 7625 & 1.7 & 6640 & 1.9 \\
\hline 2019/9/4 & 7500 & 1.6 & 6515 & 1.6 \\
\hline $2019 / 8 / 21$ & 7385 & -2.8 & 6410 & -3.1 \\
\hline $2019 / 8 / 7$ & 7595 & -1.0 & 6615 & -1.0 \\
\hline 2019/7/10 & 7675 & 2.0 & 6685 & 2.1 \\
\hline $2019 / 6 / 27$ & 7525 & -1.6 & 6545 & -1.7 \\
\hline 2019/6/12 & 7645 & -5.7 & 6660 & -6.3 \\
\hline $2019 / 5 / 28$ & 8110 & 0.6 & 7105 & 0.7 \\
\hline $2019 / 5 / 14$ & 8060 & -0.9 & 7055 & -1.1 \\
\hline $2019 / 4 / 27$ & 8135 & 2.5 & 7130 & 2.7 \\
\hline 2019/4/13 & 7940 & 1.9 & 6945 & 2.2 \\
\hline 2019/3/29 & 7990 & 1.0 & 6975 & 1.2 \\
\hline 2019/3/1 & 7910 & 3.5 & 6895 & 3.9 \\
\hline $2019 / 2 / 15$ & 7640 & 0.7 & 6635 & 0.8 \\
\hline 2019/1/29 & 7590 & 1.4 & 6585 & 1.7 \\
\hline 2019/1/15 & 7345 & 1.5 & 6355 & 1.7 \\
\hline
\end{tabular}

Petro-finance market. As shown in Fig. 12, the daily turnover of crude oil of INE is only half of that of WTI, which shows low liquidity of China's crude oil futures. Moreover, individuals and domestic customers are the main participants in China's crude oil futures market, resulting in a 


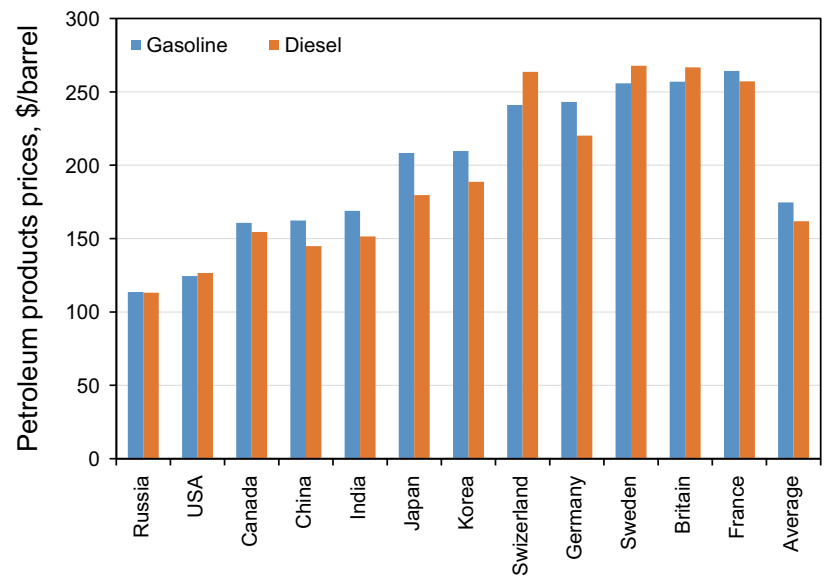

Fig. 11 Comparison of petroleum products prices between different countries. Source: GlobalPetrolPrices.com

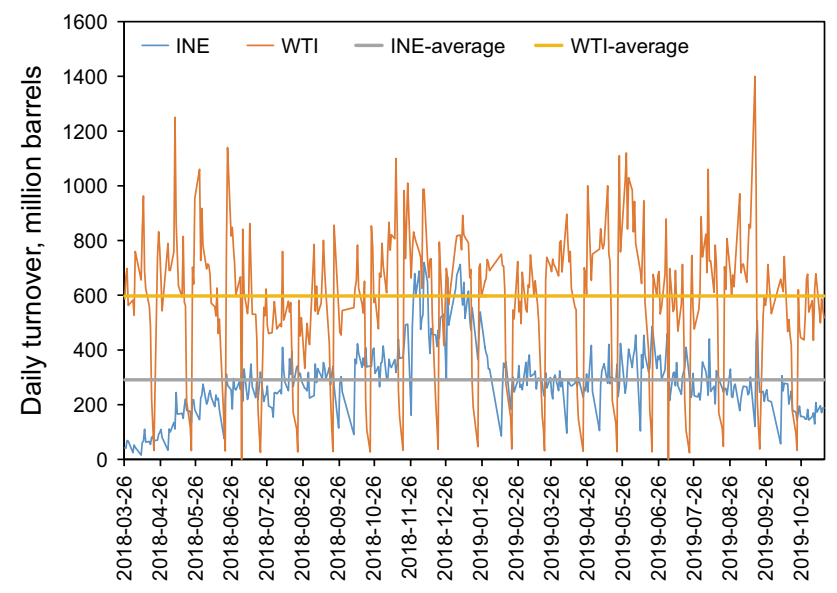

Fig. 12 Comparison of daily turnover of crude oil futures between INE and WTI. Source: Wind; investing.com

lack of openness and internationality. Thirdly, types of crude oil futures contracts are not diversified enough, and non-transparent information disclosure system may lead to the inability to obtain timely market trading information and position changes (Shi et al. 2018).

\subsection{Excess oil refining capacity}

China's oil industry has faced rapid growth in refining capacity to satisfy growing domestic demand for petroleum products (Walls 2010; Lin and Xie 2015). As shown in Fig. 13, China's oil refining capacity exceeded 800 million tonnes by 2018 , accounting for $15.6 \%$ of the world's total capacity. In addition to 2015 and 2016, the growth of China's refining capacity remains well above the world average. Further expansion of oil refining capacity causes serious structural excesses in China. As a result, the national average

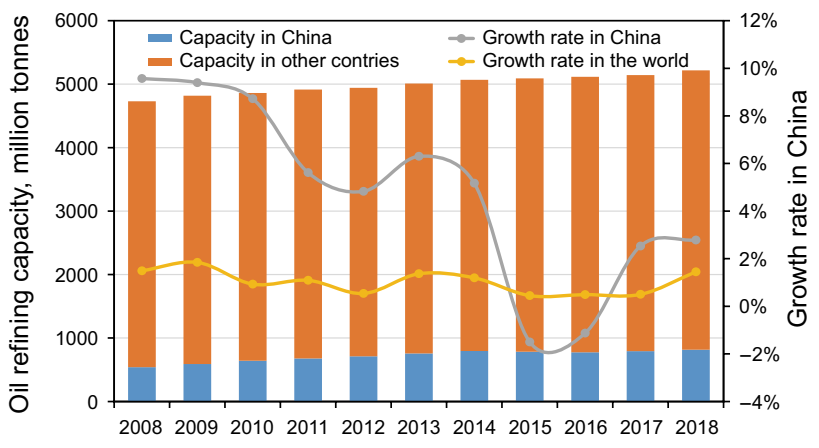

Fig. 13 Oil refining capacity and growth rate in China and the world. Source: BP statistical review of world energy, 2019

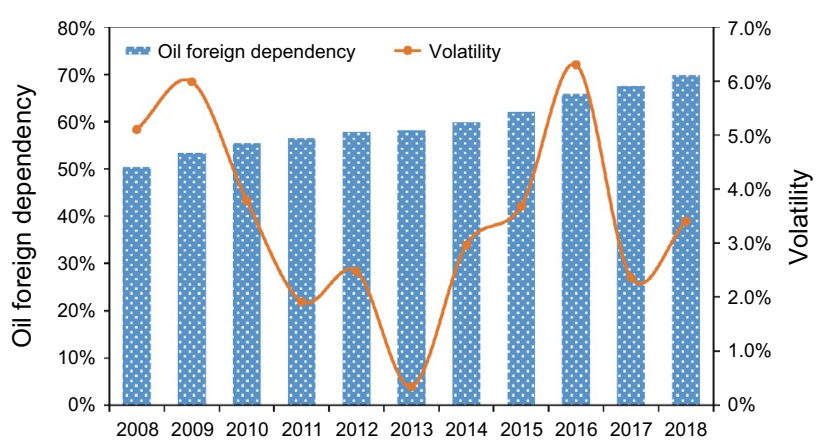

Fig. 14 China's oil external dependency. Source: National Bureau of Statistics of China; CNPC Economic \& Technological Research Institute

operating rate of refineries was only $72.9 \%$, being the lowest in the world. Moreover, the oil refining surplus capacity is estimated to rise to 120 million tonnes by 2019 (Liu and Jiang 2019). China's overcapacity of petroleum refining is expected to have reached its highest level (Pan et al. 2017). What's worse is that with the opening of crude oil imports and slowdown in domestic economic growth, overcapacity may be more serious than expected.

\subsection{High external dependency}

China is the world's largest oil importer, with net imports of 418.3 million tonnes in 2018 (BP 2019). As shown in Fig. 14, China's crude oil external dependence rose to over $70 \%$ in 2018, hitting a new record. China's growing oil imports indicate the rise of energy security as a serious issue (Leung 2011; Wu 2014). Based on the established indicator system, China's oil security level was examined to be seriously threatened and generally declining from 2001 to 2015 (Wang et al. 2018). Annual economic losses caused by high external dependency were estimated to be between $\$ 7.58$ billion and $\$ 168.24$ billion (Chen et al. 2018). Also, 
China's petroleum industry is facing a variety of risks from the supply chain perspective. These risks are defined as potentially negative impacts arising from an adverse situation such as oil disruption (Zhao and Chen 2014). Primary risks are mainly related to energy and financial flows, such as oil supply risk, geopolitical risk, oil price volatility and exchange rate volatility (Shao et al. 2017). To control the above risks, it is urgent to establish a national strategic petroleum reserve (SPR), as well as to construct an early warning indicator system to reflect the oil security level accurately. Currently, China has established petroleum reserve bases in Zhenhai, Zhoushan, Huangdao, Dalian, Dushanzi, Tianjin and Lanzhou. China's strategic petroleum reserve capacity is predicted to increase to approximately 503 million barrels by the end of 2020, equivalent to 90 days of net oil imports (CNPC 2019).

\subsection{Environment pollution}

With increasing environmental concern and the promotion of energy transition, reducing air pollution caused by petroleum refining and consumption becomes the center of the petroleum industry transformation. As such, the standard for petroleum products quality has been becoming stricter. As shown in Table 4, the Chinese government is promoting the National emission standard VI (National VI) for gasoline and diesel. To upgrade the quality of the petroleum products as soon as possible, local refineries have to reduce the use of fluid catalytic cracking naphtha suitably. Meanwhile, they are urged to increase the capacity of reformers, alkylation and isomerization units (Liu et al. 2008). However, this upgrade will create additional production costs for petroleum products and weaken refineries' competitiveness. More importantly, China's fuel quality monitoring legislation and system are not perfect yet, failing to provide a reasonable guarantee of the quality of petroleum products (Kavanagh 2014). Therefore, most enterprises do not have enough incentive to improve their products.

To promote sustainable development, eight countries have announced the phase-out planning of fuel vehicles, including Norway, Netherlands, India, Germany, Ireland, Scotland, Britain and France. China is also considering to join them. To deal with environmental problems caused by the petroleum and gas industry, the Ministry of Ecology and Environment enacted the Notice on further strengthening the management of environmental impact assessment for the oil and gas industry in December 2019. These moves would

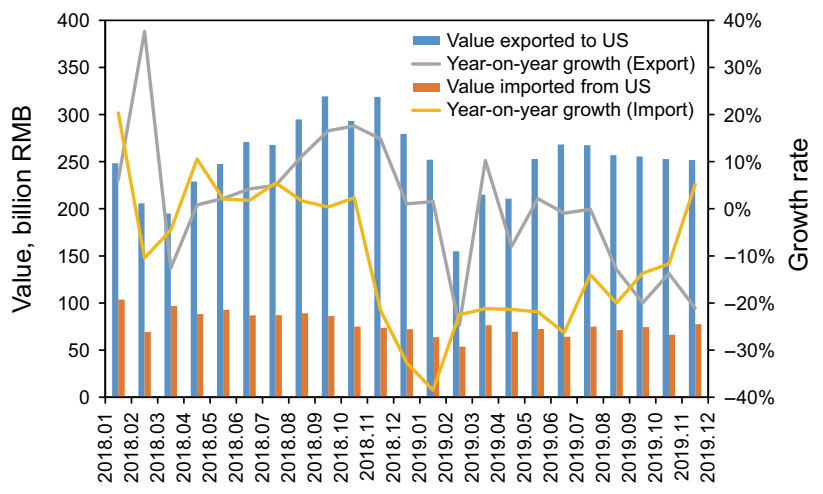

Fig. 15 Trade scale between the USA and China. Source: General Administration of Customs, China

Table 4 Schedule of quality upgrade of petroleum products in China

\begin{tabular}{|c|c|c|c|c|c|c|}
\hline $\begin{array}{l}\text { Emission standards for } \\
\text { gasoline }\end{array}$ & National I ${ }^{\mathrm{a}}$ & National II & $\begin{array}{l}\text { National III (Euro } \\
\text { III) }\end{array}$ & $\begin{array}{l}\text { National IV (Euro } \\
\text { IV) }\end{array}$ & $\begin{array}{l}\text { National V (Euro } \\
\text { V) }\end{array}$ & National VI A/B \\
\hline Execution time & 2000 & 2003 & 2005 & 2010 & 2014 & 2019 \\
\hline Sulfur, ppm & $\leq 800$ & $\leq 500$ & $\leq 150$ & $\leq 50$ & $\leq 10$ & $\leq 10$ \\
\hline Benzene, wt\% & $\leq 2.5$ & $\leq 2.5$ & $\leq 1.0$ & $\leq 1.0$ & $\leq 1.0$ & $\leq 0.8$ \\
\hline Olefin, vol\% & $\leq 35$ & $\leq 35$ & $\leq 30$ & $\leq 28$ & $\leq 24$ & $\leq 18 / 15$ \\
\hline Diesel & National $\mathrm{I}^{\mathrm{a}}$ & National II & National III & National IV & National V & National VI \\
\hline Execution time & 2000 & 2003 & 2009 & 2013 & 2016 & 2019 \\
\hline Sulfur, ppm & $\leq 2000$ & $\leq 500$ & $\leq 350$ & $\leq 50$ & $\leq 10$ & $\leq 10$ \\
\hline Cetane & $\geq 45 / 40$ & $\geq 49$ & $\geq 49$ & $\geq 49$ & $\geq 51$ & $\geq 51$ \\
\hline $\mathrm{PAHs}^{\mathrm{c}}, \%$ & - & - & $\leq 11$ & $\leq 11$ & $\leq 11$ & $\leq 7$ \\
\hline
\end{tabular}

${ }^{a}$ National I indicates National emission standard I for gasoline and diesel

${ }^{\mathrm{b}}$ In terms of sulfur content, National emission standards III, IV and VI (National III, IV, and VI) keep consistent with European emission standards III, IV, and V (Euro III, IV, and V), respectively

${ }^{\mathrm{c}} \mathrm{PAHs}$ indicate polycyclic aromatic hydrocarbons 
cause a massive shock to the petroleum industry, compelling it to transform in the future.

\subsection{Unstable international trading relationship}

In May 2018, the USA announced to retaliate 25\% tariffs on $\$ 50$ billion worth of Chinese exports to the USA, raising a new-round between the two most considerable economic powers. Inevitably, the disputes will disrupt regular trade between the two countries even the world. As shown in Fig. 15, monthly exports and imports between the USA and China in 2019 have a significant decline at an average rate of $-8 \%$ and $-19 \%$. Additionally, the US-China trade disputes may affect China's petroleum market. The USA is the tenth-largest source of China's crude oil imports, from which China imported crude oil of 84.5 million barrels in 2018, accounting for $11.3 \%$ of US exports of crude oil and $3.8 \%$ of China's imports of crude oil. However, as seen in Table 5, China's imports from the USA of crude oil has dramatically decreased since July 2018 and accumulated crude oil imports for the first three quarters in 2019 is only $56.9 \%$ of that of 2018.

Moreover, the dispute causes spill-over effects for oilexporting countries in African, thereby disturbing global oil markets (Olayungbo 2019). In August 2019, China declared to levy 5\% tariffs on crude oil imported from the USA, as its tit-for-tat measures against the USA. As a consequence, international oil prices dropped by $4 \%$ immediately (Kumar 2019). To conclude, the US-China trade disputes may add uncertainties to international oil markets, causing an increase in price risks faced by domestic petroleum enterprises.

\section{Countermeasures to improve China's petroleum market}

\subsection{Market deregulation}

\subsubsection{Industry structure and ownership}

It is a historical necessity to implement state ownership of oil and natural gas resources that relate to the core interest of the nation. However, the nationalization of oil companies has suppressed the vitality and competitiveness of China's petroleum industry. This is because that national oil companies (NOCs) undertake the burden of unproductive assets and social responsibilities, and their corporate governance lacks transparency (Andrews-Speed 2015). A mixed-ownership reform of NOCs, which turns private and state-owned enterprises from competitors into partners, is expected to

Table 5 Crude oil trade between the USA and China. Sources: EIA, General Administration of Customs, China

\begin{tabular}{|c|c|c|c|c|c|}
\hline Date & $\begin{array}{l}\text { Crude oil imported from the } \\
\text { USA (thousand barrels) }\end{array}$ & $\begin{array}{l}\text { US exports of crude oil } \\
\text { (thousand barrels) }\end{array}$ & Percentage $(\%)$ & $\begin{array}{l}\text { China's imports of crude oil } \\
\text { (thousand barrels) }\end{array}$ & Percentage $(\%)$ \\
\hline 2018.01 & 10,236 & 42,221 & 24.2 & 177,169 & 5.8 \\
\hline 2018.02 & 11,522 & 48,589 & 23.7 & 145,247 & 7.9 \\
\hline 2018.03 & 14,553 & 61,050 & 23.8 & 165,817 & 8.8 \\
\hline 2018.04 & 11,844 & 57,581 & 20.6 & 169,131 & 7.0 \\
\hline 2018.05 & 10,698 & 64,080 & 16.7 & 179,214 & 6.0 \\
\hline 2018.06 & 11,562 & 68,366 & 16.9 & 169,705 & 6.8 \\
\hline 2018.07 & 10,920 & 71,509 & 15.3 & 178,559 & 6.1 \\
\hline 2018.08 & N. A. ${ }^{a}$ & 57,619 & N. A. & 196,078 & N. A. \\
\hline 2018.09 & N. A. & 60,453 & N. A. & 195,931 & N. A. \\
\hline 2018.10 & N. A. & 69,951 & N. A. & 216,064 & N. A. \\
\hline 2018.11 & 250 & 72,013 & 0.3 & 238,516 & 0.1 \\
\hline 2018.12 & 2938 & 74,109 & 4.0 & 211,317 & 1.4 \\
\hline 2019.01 & N. A. & 79,830 & N. A. & 183,856 & N. A. \\
\hline 2019.02 & 4050 & 83,721 & 4.8 & 166,711 & 2.4 \\
\hline 2019.03 & 3183 & 83,196 & 3.8 & 179,180 & 1.8 \\
\hline 2019.04 & 1871 & 85,276 & 2.2 & 206,052 & 0.9 \\
\hline 2019.05 & 7665 & 89,908 & 8.5 & 202,018 & 3.8 \\
\hline 2019.06 & 8749 & 94,776 & 9.2 & 197,623 & 4.4 \\
\hline 2019.07 & 7105 & 83,512 & 8.5 & 192,900 & 3.7 \\
\hline 2019.08 & 7629 & 84,550 & 9.0 & 194,610 & 3.9 \\
\hline 2019.09 & 6034 & 92,755 & 6.5 & 186,346 & 3.2 \\
\hline
\end{tabular}

${ }^{\mathrm{a} N}$. A. $=$ Not available 
activate the oil industry further. To promote the ownership reform of NOCs, it is urgent to carry out business restructuring and classification, formulate implementation roadmap and timetable, and explore the establishment of equity incentives and employee shareholding (Xu et al. 2018).

\subsubsection{Pricing and anti-monopoly regulation}

State-owned enterprises play a dominant role in the petroleum industry. Such an administrative monopoly will lead to the losses of management efficiency and social welfare. In order to fundamentally improve this kind of situation, the following suggestions should be considered. As mentioned above, three state-owned petroleum enterprises have privileges and exclusive rights in some fields, such as the proprietary rights to oil exploration. Accordingly, it is expected to withdraw these privileges and treat private enterprises fairly (Sheng et al. 2015). For example, allowing third-party access is an effective way to improve management performance of the downstream oil supply chain given the adequate residual capacity of the pipeline network (Yuan et al. 2019). The establishment of National Pipe Network Corporation in December 2019 separates pipeline transportation from production and sales, which is conducive to promoting market competition and improving the efficiency of resource allocation. Moreover, it is of great importance to establish a legal and judicial anti-monopoly system, along with encouraging the public (not only competing enterprises) to directly participate in the prosecution system for administrative monopolies (Sheng and Qian 2015).

Substantial progress has been made in opening up the petroleum market, but much more work remains to be done, especially in the petroleum products pricing mechanism (Lin and Liu 2013). China's existing pricing mechanism still lacks transparency. To improve the situation, the government can move to develop a more transparent market-based pricing system by setting clear rules and conditions or adopting automatically formula-based pricing methods (Paltsev and Zhang 2015; Wang et al. 2016a). It should be noted that social protection measures in response to oil price reforms are also needed in case of their negative impacts on China's macro-economy.

\subsection{Refining capacity elimination}

Domestic oil refining capacity has been increasing because the local governments blindly support local refining and chemical enterprises. In order to eliminate this kind of overcapacity, the reform of the factor markets should be accelerated, weakening the dominant position of government in factor allocation. At the same time, the soft budgetary constraints should be further hardened, and the proportion of own funds in corporate investment should be raised to reduce risk externalization. Moreover, it is encouraged to improve local fiscal transparency and democratization, so that local government will focus more on social management, infrastructure and public service. Finally, it is expected to strengthen the financial constraint mechanism, incentive constraint mechanism and exit mechanism of state-owned enterprises, and to restrict the government from providing financial assistance to poorly run state-owned refineries.

As for the elimination of obsolete refining capacity, there are mainly two approaches: one is to close down existing refineries and build new refineries that meet stricter environmental standards; the other is to upgrade existing refining facilities with advanced technology. The latter is likely to be a more economical option for private enterprises. Moreover, the merger of small and medium-sized refineries is advocated, so as to achieve economies of scale. At the same time, the construction of integrated refining and chemical enterprises is encouraged to maximize the benefits of the industrial chain. Also, the government should call for more cooperation between private and state-owned refineries to improve resource utilization.

From a macroscopic point of view, it is significant to optimize the industrial layout and promote industrial intelligence for the whole industry's efficiency. Firstly, petroleum refineries are encouraged to take the initiative to integrate traditional businesses with new and high technologies such as Big Data, Cloud Computing, Internet of Things and Artificial Intelligence. Secondly, more efforts are required on the research and development of low-carbon technologies including green exploitation and drilling. Lastly, petroleum enterprises should make use of their advantage in techniques and equipment in exploring and developing renewable energy. For instance, they can produce geothermal energy using abandoned oil and gas wells.

\subsection{Oil supply diversification}

Diversification is an effective way to avoid oil supply disruptions (Vivoda 2009). Conventional approaches to diversifying oil supply include increasing domestic production, enriching sources of oil imports, enhancing overseas investment, and establishing strategic petroleum reserves. Abundant hydrocarbon resources characterize China, but they are not evenly distributed. Accordingly, more efforts should be made to explore and exploit oil-rich zones, particularly in China's eight major basins. These basins are located in Songliao, Bohai Bay, Sichuan, Erdos, Tarim, Junggar, Qaidam and the Pearl River Mouth, respectively. Moreover, developing unconventional oil can boost domestic production in the long run. To produce more unconventional oil, eliminating related technical barriers as soon as possible is necessary, of which the key lies in the construction of pilot areas for research and development of low-permeability tight 
oil reservoirs and shale oil reservoirs (Fu 2014; Chen et al. 2016).

Expanding China's petroleum trading network by promoting diversifying its sources of oil imports is vital for the stability of the oil supply. Current sources of China's oil imports mainly include Russia, Saudi Arabia, Angola, Iraq and Oman, from which oil imports account for over half of total imports. In the future, increasing more imports from politically stable regions with abundant resources like Canada is necessary (Sun et al. 2014). Moreover, it is suggested to reduce the reliance on high-risk routes such as the Malacca Strait and actively promote the construction of transnational oil pipelines such as China-Russian, ChinaKazakhstan, and maybe China-Myanmar pipelines to facilitate oil transport (Sun et al. 2014).

Overseas petroleum investment is also regarded as one of the essential means to address growing energy security concerns (Wu 2014). At present, the investment has been mainly led by NOCs such as CNPC, SINOPEC and CNOOC. In recent years, it has made much progress. For example, CNPC's crude oil production from overseas projects reached 23.0 million tonnes in 2019, up 8.3\% from 2018 (CNPC 2020). Nonetheless, it is still of great importance to improve the competitiveness of Chinese NOCs with international petroleum companies (Sun et al. 2017a, b). Especially, relying on the initiative of One Belt and One Road (OBOR), China should take an active part in the development of petroleum resources in those countries along OBOR. Notably, many overseas investment decisions by Chinese NOCs have been misguided in commercial terms due to their noncommercial obligations. Even though securing oil supply to China should be given priority, keeping Chinese NOCs efficient and competitive is extremely important in the long term, which is helpful for their sustainable development and the expansion of China's influence in the international oil market.

The necessity to establish state strategic petroleum reserves and enterprise strategic petroleum reserves should be emphasized. Sufficient SPR is critical for addressing supply shortages over a short time. China intends to increase its SPR to 90 days of net imports over the future 15 years, reported in its published policies about SPR (Li et al. 2017). It is ideal to purchase SPR at the lowest price. Moreover, SPR location is considered to be crucial for the timely supply of oil and is determined by many factors. These factors include construction and transportation costs, distance from major oil-consuming cities, geological conditions and supporting infrastructure. Accordingly, it is recommended to keep caution in SPR site selection and do a cost-benefit analysis.

China's energy efficiency has been at a low level, without any significant improvement (Xie et al. 2015). Therefore, apart from the above four ways, energy efficiency improvement can also greatly contribute to a decline in pressure on oil supply and external dependency. What's most important is that nearly all the given solutions have costs, especially increasing domestic oil production. Further work is still needed to explore the development priorities of these options and the optimal development scale, such as the optimal scale of SPR, in order to ensure stable oil supply at the lowest costs.

\subsection{Anti-risk capability improvement}

Faced with volatile international oil prices, Chinese petroleum enterprises should improve their ability to cope with price risks. In particular, due to the ongoing US-China trade war and global political tensions, international oil markets will experience a hard period. To address this issue, domestic petroleum enterprises should learn to use financial derivatives to control oil price risks, and the Chinese government should improve the domestic oil derivatives market and launch oil options as soon as possible.

\section{Conclusions}

Petroleum industry plays a vital role in the foundation of the national economy of China. Despite the fact that several reforms were implemented successfully in the past decades, there are still some unresolved problems. Moreover, with the new-normal economy, transition to green energy and international trade disputes, new challenges and problems are emerging. This study presents current challenges and corresponding measures through a review of the historical development of China's petroleum industry.

The historical overview of China's petroleum market is conducted from the aspects of administration, industrial and market structures, oil imports and pricing mechanisms, and five challenges are summarized, namely lack of marketization, excess oil refining capacity, high external dependency, environment pollution and unstable international trading relationship. To address the challenges and problems, the corresponding countermeasures are proposed. Firstly, it is encouraged to promote market reform, as well as establish a more transparent market-based pricing system by setting clear rules and conditions or adopting automatically formula-based pricing methods. Secondly, the Chinese government should call for the merger of small and mediumsized refineries and the construction of integrated refining and chemical enterprises, thereby to accelerate the phase-out of obsolete refining capacity. Thirdly, diversification of the oil supply sources can be contributed by increasing domestic production, enriching the source of oil imports, enhancing 
overseas investment and establishing strategic petroleum reserves. Last but not least, domestic petroleum enterprises' anti-risk capability should be improved in response to volatile oil prices brought by international trade disputes.

Acknowledgements The authors gratefully acknowledge the support provided by the National Natural Science Foundation of China (Nos. 71974197 and 71774171) and Beijing Social Science Fund (No. 18GLC084).

Open Access This article is licensed under a Creative Commons Attribution 4.0 International License, which permits use, sharing, adaptation, distribution and reproduction in any medium or format, as long as you give appropriate credit to the original author(s) and the source, provide a link to the Creative Commons licence, and indicate if changes were made. The images or other third party material in this article are included in the article's Creative Commons licence, unless indicated otherwise in a credit line to the material. If material is not included in the article's Creative Commons licence and your intended use is not permitted by statutory regulation or exceeds the permitted use, you will need to obtain permission directly from the copyright holder. To view a copy of this licence, visit http://creativecommons.org/licenses/by/4.0/.

\section{References}

Andrews-Speed P. China's oil and gas industry: stranded between the plan and the market. In: Belyi AV, Talu K, editors. States and markets in hydrocarbon sectors. Basingstoke: Palgrave Macmillan; 2015. p. 214-39.

Andrews-Speed P, Cao Z. Prospects for privatization in China's energy sector. In: Green S, Liu GS, editors. Exit the dragon? Privatization and state ownership in China. London: Royal Institute for International Affairs; 2005. p. 196-213.

Bouri E, Chen Q, Lien D, et al. Causality between oil prices and the stock market in China: the relevance of the reformed oil product pricing mechanism. Int Rev Econ Finance. 2017;48:34-48. https ://doi.org/10.1016/j.iref.2016.11.004.

BP. BP statistical review of world energy 2019. 2019. http://www. bp.com/statisticalreview. Accessed June 2019.

Chen JJ, Wang N, Tang HJ, et al. Impact of sustained low oil prices on China's oil \& gas industry system and coping strategies. Nat Gas Ind. 2016;3:181-6. https://doi.org/10.1016/j. ngib.2016.05.001.

Chen SY, Li MT, Zhang Q, et al. Study on the oil import/export quota allocation mechanism in China by using a dynamic gametheoretic model. Energy Procedia. 2017;105:3856-61. https:// doi.org/10.1016/j.egypro.2017.03.788.

Chen ZM, Zeng SP, Lester L, et al. Economic cost of China's oil import: Welfare estimation for 2001-2015. Resour Conserv Recycl. 2018;132:158-67. https://doi.org/10.1016/j.resco nrec.2018.02.001.

Deloitte. China gasoline retailing development trends report 2019. https ://www2.deloitte.com/content/dam/Deloitte/cn/Documents/energ $\mathrm{y}$-resources/deloitte-cn-er-china-gasoline-retailing-developmen t-trends-report-zh-190527.pdf. Accessed May 2019.

China National Offshore Oil Corporation (CNOOC). Annual report in 2019. https://www.cnoocltd.com/module/download/down. jsp?i_ID=15303408\&colID=3881. Accessed April 2020.

China National Petroleum Corporation (CNPC). Annual report in 2019. http://www.petrochina.com.cn/petrochina/ndbg/20200 3/597a083311044a799810ed977488f803/files/20d26be30d 3b43239ddb773e4e1b3a94.pdf. Accessed Mar 2020.
China National Petroleum Corporation (CNPC). China's oil strategic reserve. http://www.cnpc.com.cn/syzs/yqcy/201912/b12112ac3e 34445bac22596f5d17e52a.shtml. Accessed Dec 2019.

China Petroleum \& Chemical Corporation (SINOPEC). Annual report in 2019. http://www.sinopec.com/listco/Resource/ Pdf/2020042303.pdf. Accessed Apr 2020.

Fu CY. China's shale gas and shale oil resources: opportunities and challenges. Energy Explor Exploit. 2014;32:759-70. https://doi. org/10.1260/0144-5987.32.5.759.

Ji Q, Zhang DY. China's crude oil futures: Introduction and some stylized facts. Finance Res Lett. 2019;28:376-80. https://doi. org/10.1016/j.frl.2018.06.005.

Kavanagh T. International fuel quality standards and their implications for Australian standards. Australian Government, Department of the Environment. 2014. https://www.environment.gov. $\mathrm{au} /$ system/files/resources/f83ff2dc-87a7-4cf9-ab24-6c25f2713f 9e/files/international-feul-quality-standards.pdf. Accessed Oct 2014.

Kojima M. Drawing a roadmap for oil pricing reform. In: Household savings in Central Eastern and Southeastern Europe: how do poorer households save? The World Bank, Washington, DC. 2013.

Kong B. China's international petroleum policy. Westport: Praeger Security International. Greenwood Publishing Group; 2010.

Kumar KD. Oil dragged into U.S.-China trade war, prices slump. https://www.reuters.com/article/us-usa-trade-china-oil/oil-spill s-into-u-s-china-trade-war-prices-slump-idUSKCN1VD22D. Accessed 24 Aug 2019.

Lee H. State owned enterprises in China: reviewing the evidence. OECD Occasional Paper. https://www.oecd.org/corporate/ca/ corporategovernanceofstate-ownedenterprises/42095493.pdf. Accessed 26 Jan 2009.

Leung GC-K. China's oil use, 1990-2008. Energy Policy. 2010;38:932-44. https://doi.org/10.1016/j.enpol.2009.10.045.

Leung GC-K. China's energy security: perception and reality. Energy Policy. 2011;39:1330-7. https://doi.org/10.1016/j.enpol .2010 .12 .005

Li R, Leung GC-K. The integration of China into the world crude oil market since 1998. Energy Policy. 2011;39:5159-66. https ://doi.org/10.1016/j.enpol.2011.05.048.

Li H, Sun RJ, Dong KY, et al. Selecting China's strategic petroleum reserve sites by multi-objective programming model. Pet Sci. 2017;14:622-35. https://doi.org/10.1007/s12182-017-0175-0.

Li Y, Wang G, Mclellan B, Chen SY, Zhang Q. Study of the impacts of upstream natural gas market reform in China on infrastructure deployment and social welfare using an SVM-based rolling horizon stochastic game analysis. Pet Sci. 2018;15:898-911. https://doi.org/10.1007/s12182-018-0238-x.

Lin BQ, Liu X. Reform of refined oil product pricing mechanism and energy rebound effect for passenger transportation in China. Energy Policy. 2013;57:329-37. https://doi.org/10.1016/j.enpol .2013.02.002.

Lin BQ, Xie X. Energy conservation potential in China's petroleum refining industry: evidence and policy implications. Energy Convers Manage. 2015;91:377-86.

Liu ZQ, Jiang XF. Domestic and international oil \& gas industry development report in 2018. Beijing: Petroleum Industry Press; 2019.

Liu HY, Yu JN, Fan Y, et al. A scenario-based clean gasoline production strategy for China National Petroleum Corporation. Pet Sci. 2008;5:285-94. https://doi.org/10.1007/s12182-008-0048-7.

Liu XY, Chen DJ, Zhang WJ, et al. An assessment of the energy-saving potential in China's petroleum refining industry from a technical perspective. Energy. 2013;59:38-49. https://doi.org/10.1016/j. energy.2013.07.049.

Ministry of Commerce, China. Total allowable volume, application conditions and application procedure of non-state trade imports 
of crude oil in 2019, Announcement No. 72 [2018]. http://www. mofcom.gov.cn/article/b/e/201809/20180902791827.shtml. Accessed in 29 Sept 2018.

Ministry of Foreign Trade and Economic Cooperation (MOFTEC), China. Circular on Issuing the Measures for Organizing the Implementation of the Import of Crude Oil and Finished Oil. http://project.mofcom.gov.cn/1800000121_23_68609_0_7.html. Accessed 13 Feb 1999.

NEA (National Energy Administration), China. Regulatory approach on oil and gas pipeline facilities fair and open. http://zjb.nea. gov.cn/Article/UploadFiles/201906/2019060316571130.pdf. Accessed May 2019.

Olayungbo OD. The US-China trade dispute: spill-over effects for selected oil-exporting countries in Africa using GVAR analysis. Transnatl Corp Rev. 2019;11:310-22. https://doi. org/10.1080/19186444.2019.1682407.

Paltsev S, Zhang DW. Natural gas pricing reform in China: getting closer to a market system? Energy Policy. 2015;86:43-56. https ://doi.org/10.1016/j.enpol.2015.06.027.

Pan LY, Liu P, Li Z. A system dynamic analysis of China's oil supply chain: over-capacity and energy security issues. Appl Energy. 2017;188:508-20. https://doi.org/10.1016/j.apene rgy.2016.12.036.

Shao YM, Qiao H, Wang SY. What determines China's crude oil importing trade patterns? Empirical evidences from 55 countries between 1992 and 2015. Energy Policy. 2017;109:854-62. https ://doi.org/10.1016/j.enpol.2017.05.063.

Sheng H, Qian P. Opening up China's markets of crude oil and petroleum products: theoretical research and reform solutions, vol. 9. Beijing: Social Science Academic Press, Series on Chinese Economics Research; 2015.

Sheng H, Zhao N, Yang JF. Administrative monopoly in China: causes, behaviors, and termination. Singapore: World Scientific Publishing Co Pte Ltd.; 2015.

Shi XP, Ji Q, Zhang DY. Evolution of international crude oil pricing mechanism and its implications to China's crude oil futures. J Environ Econ. 2018;3:121-34.

Sun M, Gao GX, Shen B. Quantifying China's oil import risks and the impact on the national economy. Energy Policy. 2014;67:605-11. https://doi.org/10.1016/j.enpol.2013.12.061.

Sun CW, Luo Y, Huang Y, et al. A comparative study on the production efficiencies of China's oil companies: a true fixed effect model considering the unobserved heterogeneity. J Clean Prod. 2017a;154:341-52. https://doi.org/10.1016/j.jclepro.2017.03.222.

Sun XL, Liu C, Chen XW, Li JP. Modeling systemic risk of crude oil imports: case of China's global oil supply chain. Energy. 2017b;121:449-65. https://doi.org/10.1016/j.energy.2017.01.018.

Tang X, Zhang BS, Feng LY, Marwan M, Afshin H. Economic impacts and challenges of China's petroleum industry: an input-output analysis. Energy. 2011;36:2905-11. https://doi.org/10.1016/j. energy.2011.02.033.

The State Council, China. Several opinions on promoting the growth stabilization and structural adjustment of imports and exports. https://www.customslawyer.cn/portal/fgk/detail/id/58681.html. Accessed 26 July 2013.

The State Council, China. Several opinions on promoting the reform of the price mechanism. http://www.gov.cn/xinwen/2015-10/15/ content_2947548.htm. Accessed 15 Oct 2015.
The State Council, China. Several opinions on supporting the steady growth of foreign trade. http://www.gov.cn/xinwen/2014-05/15/ content_2680020.htm. Accessed 15 May 2014.

Vivoda V. Diversification of oil import sources and energy security: a key strategy or an elusive objective? Energy Policy. 2009;37:4615-23. https://doi.org/10.1016/j.enpol.2009.06.007.

Walls WD. Petroleum refining industry in China. Energy Policy. 2010;38:2110-5. https://doi.org/10.1016/j.enpol.2009.06.002.

Wang JW, She JY. Optimization of imported crude oil purchasing strategy for local refineries in China. Int Pet Econ. 2017;25(5):46-50.

Wang Y, Xiang E, Cheung A, et al. International oil price uncertainty and corporate investment: evidence from China's emerging and transition economy. Energy Econ. 2016a;61:330-9. https://doi. org/10.1016/j.eneco.2016.11.024.

Wang Z, Zhang A, Liu MM. China crude oil imports and oil marketoriented reform. China Oil Gas. 2016b;2:9-15.

Wang QS, Tang HR, Yuan XL, et al. An early warning system for oil security in China. Sustainability. 2018;10:283. https://doi. org/10.3390/su10010283.

Wen XQ, Bouri E, Roubaud D. Does oil product pricing reform increase returns and uncertainty in the Chinese stock market? Q Rev Econ Finance. 2018;68:23-30. https://doi.org/10.1016/j. qref.2017.08.003.

Wu K. China's energy security: oil and gas. Energy Policy. 2014;74:4 11. https://doi.org/10.1016/j.enpol.2014.05.040.

Xie W, Sheng PF, Guo XH. Coal, oil, or clean energy: Which contributes most to the low energy efficiency in China? Util Policy. 2015;35:67-71. https://doi.org/10.1016/j.jup.2015.05.003.

Xie N, Yan ZJ, Zhou Y, Huang WI. China's optimal stockpiling policies in the context of new oil price trend. Energy Policy. 2017;105:332-40. https://doi.org/10.1016/j.enpol.2017.03.008.

$\mathrm{Xu}$ D, Cui YK, Zhang L, et al. Progress of mixed ownership reform of CNPC in 2016-2018 and follow-up reform suggestions. Int Pet Econ. 2018;26:12-7.

Yang J, Geng HZ, Wang XK, et al. Study on the control strategy of China's refined oil government-also on the reform of China's refined oil pricing mechanism. Finance Trade Econ. 2009;6:109-14.

Yang X, Wan H, Zhang Q, et al. A scenario analysis of oil and gas consumption in China to 2030 considering the peak CO2 emission constraint. Pet Sci. 2016;13:370-83. https://doi.org/10.1007/ s12182-016-0089-2.

Yuan M, Zhang HR, Wang BH, et al. Future scenario of China's downstream oil supply chain: an energy, economy and environment analysis for impacts of pipeline network reform. J Clean Prod. 2019;232:1513-28. https://doi.org/10.1016/j.jclepro.2019.05.340.

Zhang J. Catch-up and competitiveness in China-the case of large firms in the oil industry. London: RoutledgeCurzon; 2004.

Zhang J, Xie MJ. China's oil product pricing mechanism: What role does it play in China's macroeconomy? China Econ Rev. 2016;38:209-21. https://doi.org/10.1016/j.chieco.2016.02.002.

Zhao C, Chen B. China's oil security from the supply chain perspective: a review. Appl Energy. 2014;136:269-79. https://doi. org/10.1016/j.apenergy.2014.09.016. 